\title{
Accounting Characteristics Of Corporations By Bonds Issuing Methods: Focused On Public Corporations In South Korea
}

\author{
Soonwook Hong, Yeungjin College, South Korea
}

\begin{abstract}
Public corporations of Korea may opt for either online auction or offline issue of bonds, the latter being a more traditional method using investment banks. These two methods have distinct advantages and disadvantages. Corporations that adopt the online issue method tend to have lower earnings management, use more conservative accounting, and enjoy superior scores on the government's assessment of management performance. This means that corporations that choose online, the more transparent issuance method, are more transparent in their accounting practices.
\end{abstract}

Keywords: Electronic Auction System; Bonds Issuance; Earnings Management; Accounting Conservatism; Government's Assessment of Management Performance

\section{INTRODUCTION}

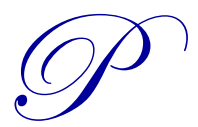

ublic corporations, established for public benefit, receive capital investments from the government for various infrastructure development projects such as water supply and sewage, electricity, roads, and harbors. Any shortfall in funds is bridged by issuing bonds in capital market. Such bonds, issued for public benefit, are called "special bonds." Public corporations may issue bonds either by appointing investment banks as arrangers (Offline, Negotiation, Indirect issuance) or through an online system (Online, Auction, Direct issuance). The two methods have distinct advantages and disadvantages. The bonds issuance process organized by investment bankers carries lesser uncertainty than the online auction system, as the online competitive bidding process may encounter the possibility of a lack of bids, and thus result in the failure of the bond issuance. On the other hand, offline issue entails higher fees and involves the disadvantage of lack of transparency, with possible lobbying. The increased overall costs due to higher fees and possible lobbying are borne by the investors and the public, or the taxpayers. Consequently, unhealthy public corporations lead to an injection of public funds raised from taxpayer's money. Online competitive bidding has practically few disadvantages except for the possibility of failure in funding. Public corporations have very high credit ratings as they are supported by the government it is safe to say that they face little risk of bankruptcy. Hence, the special bonds issued by public corporations do not have a significant chance of funding failure.

This paper assumes that a corporation displays unique characteristics depending on its choice between the two available methods of bond issuance. In particular, this paper aims to identify the characteristics of public corporations in Korea that issue special bonds by considering attributes such as earnings management, accounting conservatism, and government scores of management assessment.

\section{HYPOTHESES DEVELOPMENT}

Ahmed et al. (2002), Zhang (2008), and Xi (2015) found that conservative accounting treatment reduces funding costs of corporations. Edwards et al. (2007) argued that transparency lowers cost of bond issuance. Seung-Hyun Oh (2006) maintained that the inactive Bond Electronic Trading System has inhibited the growth of bond market in Korea. 
The process of recording results of bond issuance in financial statements, either through the online or offline method, is identical. Typically, the bond issuance method is not determined through careful consideration of relative advantages and disadvantages between the two available methods, but at the discretion of managers-in-charge. Therefore, the accounting characteristics of firms that opt for online bond issuance, which has far more advantages than the offline method, may be different from those of firms that issue bonds using the offline method. Offline issue entails high costs. Often, in an attempt to reduce the amount of issuance fees that are highly visible, they may be concealed as a part of the interest rate. It has been shown that offline issue involves more disadvantages than online issue. Agency costs are incurred since the managers who are responsible for bond issue opt for offline issuance because it is easier, as the entire issue amount is underwritten by arrangers. The offline issuance scheme may involve improper practices. While this has not been confirmed, it can be presumed as caution.

For these reasons, it is hypothesized the firms that issue bonds online are less likely to use earnings management than the firms that issue bonds offline. Moreover, it is also supposed the firms that opt for online bond issue use more conservative accounting treatment than the firms that issue bond offline. Lastly, it is presumed the firms that issue bonds online are likely to have better scores on the government's management assessment than the firms that issue bonds offline.

Hypothesis 1: The firms that issue bonds online are less likely to use earnings management than the firms that issue bonds offline.

Hypothesis 2: The firms that opt for online bond issue use more conservative accounting treatment than the firms that issue bond offline.

Hypothesis 3: The firms that issue bonds online are likely to have better scores on the government's management assessment than the firms that issue bonds offline.

\section{THE MODEL}

This paper focused on public corporations in Korea that issued bonds during 2001-2013. To obtain data for central public corporations, we used the Public Corporation Management Information Disclosure System (www.alio.go.kr), and for local public corporations, data available on the Local Public Corporation Management Information Disclosure System (www.cleaneye.go.kr) was used. We relied on the websites of individual public corporations to obtain data for the years preceding the last five years.

The most used measure, Modified Jones Model (Dechow et al. 1995) was used to detect the earnings management. The models of Ball and Shivakumar (2008), and Hye-Jeong Nam et al. (2013) were employed to measure the level of conservatism in public corporations that are not listed on the stock market. The scores of the government's management assessment have been determined by firm value model, and variables that are generally known to affect firm value are included as control variables

$$
D A C C_{t}=\beta_{0}+\beta_{1} O N L I N E_{t}+\beta_{2} L E V_{t}+\beta_{3} G R O W T H_{t}+\beta_{4} C F O_{t}+\beta_{5} S I Z E_{t}+\beta_{6} L O S S_{t}+\Sigma Y D+\Sigma I N D+\varepsilon_{t}
$$

DACC: Discretionary Accruals

ONLINE: The amount of bonds issued Online $>$ Offline then 1, otherwise 0

LEV: Leverage $=$ Total Liabilities $/$ Total Assets

GROWTH: $\Delta$ Sales scaled by Total Assets

CFO: Cash Flows from Operating scaled by Total Assets

SIZE: The natural logarithm of the Total Assets 
LOSS: The earnings $<0$ then 1 , otherwise 0

YD: Year Dummy

IND: Industry Dummy

$$
\begin{aligned}
& \text { TAC } C_{t}=\beta_{0}+\beta_{1} \text { ONLINE }_{t}+\beta_{2} \text { CFO }_{t}+\beta_{3} \text { DCFO }_{t}+\beta_{4} \text { ONLINE }_{t}^{*}{ }^{*} C_{F O}+\beta_{5} \text { ONLINE }_{t} * D C F O_{t} \\
& +\beta_{6} C F O_{t} * D C F O_{t}+\beta_{7} \text { ONLINE }_{t}{ }^{*} C F O_{t} * D C F O_{t}+\beta_{8} \text { GROWTH }_{t}+\beta_{9} P P E_{t}+\Sigma Y D+\Sigma I N D+\varepsilon_{t}
\end{aligned}
$$

TAC: Total Accruals=(Net Income-Cash Flows from Operating) scaled by Total Assets

DCFO: Cash Flows from Operating $<0$ then 1, otherwise 0

PPE: Property, Plant and Equipment scaled by Total Assets

$$
\text { EVALUATION }_{t}=\beta_{0}+\beta_{1} \text { ONLINE }_{t}+\beta_{2} L E V_{t}+\beta_{3} \text { GROWTH }_{t}+\beta_{4} R O A_{t}+\beta_{5} \operatorname{SIZE}_{t}+\beta_{6} L O S S_{t}+\Sigma Y D+\Sigma I N D+\varepsilon_{t}
$$

EVALUATION: Government's assessment of management performance

ROA: Return on Total Assets

\section{EMPIRICAL RESULTS}

Table 1. Descriptive statistics

\begin{tabular}{l|c|c|c|c|c|c}
\hline \multicolumn{1}{c|}{ Variable } & Sample size & Mean & SD & Median & Min & Max \\
\hline DACC & 393 & 0.006 & 0.085 & 0.001 & -0.341 & 0.631 \\
\hline EVALUATION & 393 & 4.369 & 0.088 & 4.389 & 3.967 & 4.566 \\
\hline ONLINE & 393 & 0.374 & 0.484 & 0.000 & 0.000 & 1.000 \\
\hline LEV & 393 & 0.593 & 0.279 & 0.576 & 0.061 & 1.747 \\
\hline GROWTH & 393 & 0.063 & 0.337 & 0.077 & -1.414 & 0.861 \\
\hline CFO & 393 & -0.009 & 0.222 & 0.013 & -1.459 & 0.454 \\
\hline ROA & 393 & 0.012 & 0.050 & 0.009 & -0.169 & 0.223 \\
\hline SIZE & 393 & 15.523 & 1.544 & 15.430 & 11.927 & 18.876 \\
\hline LOSS & 393 & 0.257 & 0.438 & 0.000 & 0.000 & 1.000 \\
\hline
\end{tabular}

(1) Refer to 'THE MODEL (1), (2), and (3)' for the definition of variables.

In Table 1, discretionary accruals (DACC) as a measure of earnings management was 0.006 , slightly greater than zero, and it appears to be reasonable. Mean of firms with online bond issue was 0.374 , meaning there are 147 firms using

\begin{tabular}{|c|c|c|c|c|c|c|c|c|c|}
\hline Variable & DACC & EVA & ONLINE & LEV & GROW & CFO & ROA & SIZE & LOSS \\
\hline DACC & 1 & & & & & & & & \\
\hline EVA & 0.076 & 1 & & & & & & & \\
\hline ONLINE & -0.030 & $0.225^{* * *}$ & 1 & & & & & & \\
\hline LEV & 0.065 & 0.001 & $0.109^{* *}$ & 1 & & & & & \\
\hline GROW & 0.056 & $0.126^{* *}$ & 0.014 & 0.001 & 1 & & & & \\
\hline $\mathrm{CFO}$ & $-0.409^{* * *}$ & $-0.152^{* * *}$ & -0.075 & $-0.278^{* * *}$ & $-0.172^{* * *}$ & 1 & & & \\
\hline ROA & -0.005 & 0.008 & 0.003 & $-0.381^{* * *}$ & 0.049 & $0.314^{* * *}$ & 1 & & \\
\hline SIZE & 0.057 & 0.046 & $0.429^{* * *}$ & $0.084^{*}$ & $-0.102^{* *}$ & 0.008 & $-0.180^{* * *}$ & 1 & \\
\hline LOSS & $-0.096^{*}$ & -0.071 & -0.082 & 0.038 & -0.054 & -0.079 & $-0.548^{* * *}$ & -0.033 & 1 \\
\hline
\end{tabular}
more online method $(=393 * 0.374)$.

Table 2. Pearson correlation matrix

(1) Refer to 'THE MODEL (1), (2), and (3)' for the definition of variables.

(2) EVA=EVALUATION, GROW= GROWTH

(3) ${ }^{* * * * *}$, and ${ }^{*}$ significant at the $1 \%, 5 \%$, and $10 \%$ level, respectively. 
Table 2 shows the correlations between each set of two variables. The correlation between DACC and ONLINE is negative which means the firms that issue bonds online use less earnings management. The correlation between EVALUATION and ONLINE is positive and it can be viewed the firms that issue bonds online get a better evaluation from the government's assessment of management performance. Since this analysis is a simple correlation, regression analysis including control variables is to be implemented.

Table 3. T-Test

\begin{tabular}{l|c|c|c}
\hline & ONLINE & OFFLINE & Difference \\
\hline DACC & 0.003 & 0.009 & $-0.006^{*}$ \\
\hline EVALUATION & 4.400 & 4.350 & $0.041^{* * *}$ \\
\hline
\end{tabular}

(1) Refer to 'THE MODEL (1), (2), and (3)' for the definition of variables.

(2) ${ }^{* * * * * *}$, and ${ }^{*}$ significant at the $1 \%, 5 \%$, and $10 \%$ level, respectively.

In table 3, firms issuing bonds offline appear to use more earnings management and have lower scores on the government's management assessment than those that issue bonds online.

Table 4. Regression analysis for earnings management

$D A C C_{t}=\beta_{0}+\beta_{1} O N L I N E_{t}+\beta_{2} L E V_{t}+\beta_{3} G R O W T H_{t}+\beta_{4} C F O_{t}+\beta_{5} S I Z E_{t}+\beta_{6} L O S S_{t}+\Sigma Y D+\Sigma I N D+\varepsilon_{t}$

\begin{tabular}{l|c|c|c}
\hline \multicolumn{1}{c|}{ Variable } & Parameter Estimate & T value & VIF \\
\hline Intercept & -0.075 & -1.61 & 0.000 \\
\hline ONLINE & $\mathbf{- 0 . 0 2 0}$ & $\mathbf{- 2 . 0 9}$ & 1.452 \\
\hline LEV & -0.011 & -0.64 & 1.368 \\
\hline GROWTH & -0.004 & -0.36 & 1.112 \\
\hline CFO & -0.174 & $-9.01^{* * *}$ & $1.99^{* *}$ \\
\hline SIZE & 0.006 & $-2.93^{* * *}$ & 1.199 \\
\hline LOSS & -0.030 & Included $^{* * 386}$ \\
\hline Year Dummy & & Included \\
\hline Industry Dummy & & 0.171 \\
\hline Adj. R & & $5.25^{* * *}$ \\
\hline F value & & 393 \\
\hline Sample size & & 310 \\
\hline
\end{tabular}

(1) Refer to 'THE MODEL (1), (2), and (3)' for the definition of variables.

(2) $\mathrm{VIF}=$ Variance Inflation Factor.

(3) ${ }^{* * * * *}$, and $^{*}$ significant at the $1 \%, 5 \%$, and $10 \%$ level, respectively.

In table 4, regression analysis was conducted with DACC as a dependent variable. Proxy of earnings management, DACC was estimated using the modified Jones model (Dechow et al. 1995). The coefficient of firms that issue bonds online was found to be negative at a significance level of 5\%, suggesting that firms issuing online use less earnings management than firms issuing bonds offline. Hong (2016) points out that earnings management has negative influence on stock returns. Chen et al. (2015) and Jo \& Kim (2007) assert that independence and transparency may decrease earnings management. The result of the regression analysis appears to support Hypothesis 1 which claims the firms that issue bonds online use less earnings management. Further, coefficients of other control variables, with adjusted $\mathrm{R}^{2}$ at $17.1 \%$ and $\mathrm{F}$ value having a significant value, did not go beyond a certain level, showing that the model seems to be fit. Additionally, there is not a problem regarding multicollinearity since every VIF value is low below 10 . 
Table 5. Regression Analysis For Conservatism

$$
\begin{aligned}
& T_{A C C_{t}}=\beta_{0}+\beta_{I} \text { ONLINE }_{t}+\beta_{2} C F O_{t}+\beta_{3} D_{C F O}+\beta_{4} \text { ONLINE }_{t}^{*} C F O_{t}+\beta_{5} \text { ONLINE }_{t}^{*}{ }^{2} C F O_{t}+\beta_{6} C F O_{t}{ }^{*} D C F O_{t} \\
& +\beta_{7} \mathrm{ONLINE}_{t} * \mathrm{CFO}_{t}{ }^{*} D C F O_{t}+\beta_{8} \text { GROWTH }_{t}+\beta_{9} P P E_{t}+\Sigma Y D+\Sigma I N D+\varepsilon_{t}
\end{aligned}
$$

\begin{tabular}{l|c|c|c}
\hline \multicolumn{1}{c|}{ Variable } & Parameter Estimate & T value & VIF \\
\hline Intercept & 0.001 & $3.32^{* * *}$ & 0.000 \\
\hline ONLINE & -0.001 & -0.56 & 2.492 \\
\hline CFO & -0.008 & $-8.04^{* * *}$ & 7.650 \\
\hline DCFO & -0.001 & -1.57 & 2.312 \\
\hline ONLINE*CFO & 0.005 & $2.81^{* * *}$ & 21.657 \\
\hline ONLINE*DCFO & -0.001 & -0.94 & 2.997 \\
\hline CFO*DCFO & -0.005 & $-6.01^{* * *}$ & 9.210 \\
\hline ONLINE*CFO*DCFO & $\mathbf{0 . 0 0 4}$ & $\mathbf{2 . 1 7 ^ { * * }}$ & $\mathbf{2 4 . 3 5 8}$ \\
\hline GROWTH & 0.004 & $4.39^{* * *}$ & 1.127 \\
\hline PPE & -0.001 & $-3.02^{* * *}$ & 1.159 \\
\hline Adj. ${ }^{2}$ & & 0.678 & \\
\hline F value & & $92.74^{* * *}$ & 393 \\
\hline Sample size & & &
\end{tabular}

(1) Refer to 'THE MODEL (1), (2), and (3)' for the definition of variables.

(2) ${ }^{* * * * *}$, and $^{*}$ significant at the $1 \%, 5 \%$, and $10 \%$ level, respectively.

In table 5, the level of conservatism of firms using online bond issue was measured using a Ball and Shivakumar (2008) Model that measures level of conservatism of non-listed corporations. The coefficient $\beta_{7}$ was positive at a significance level of $5 \%$, meaning that firms issuing bonds online are engaged in more conservative accounting treatment than firms issuing bonds offline. Ahmed et al. (2002), Zhang (2008), and Xi (2015) suggest that conservatism lowers the cost of capital and Ahmed \& Duellman (2007), Haw et al. (2015) argue that the firms with good corporate governance and higher transparency are more conservative in accounting. The key features of the firms that issue bonds online are low cost of capital and high transparency. The result of the regression analysis shows the firms that issue bonds online are more conservative in accounting, therefore, seemingly support Hypothesis 2 . The explanatory power stood at $67.8 \%$, a high level, and the F value had a significant value, showing that the analysis model appears to be fit. VIF values of the independent variables except the interacting variables are below 10 , therefore, multicollinearity is not an issue.

Table 6. Regression analysis for evaluation

EVALUATION $_{t}=\beta_{0}+\beta_{1}$ ONLINE $_{t}+\beta_{2} L E V_{t}+\beta_{3}$ GROWTH $_{t}+\beta_{4} R O A_{t}+\beta_{5} S_{Z I Z E_{t}}+\beta_{6} L O S S_{t}+\Sigma Y D+\Sigma I N D+\varepsilon_{t}$

\begin{tabular}{|c|c|c|c|}
\hline Variable & Parameter Estimate & T value & VIF \\
\hline Intercept & 4.236 & $72.53^{* * *}$ & 0.000 \\
\hline ONLINE & 0.028 & $2.84^{* * *}$ & 1.418 \\
\hline LEV & 0.005 & 0.27 & 1.890 \\
\hline GROWTH & 0.038 & $2.99^{* * *}$ & 1.082 \\
\hline ROA & 0.106 & 0.93 & 2.355 \\
\hline SIZE & 0.006 & $1.80^{*}$ & 1.574 \\
\hline LOSS & -0.022 & $-1.89^{*}$ & 1.655 \\
\hline Year Dummy & & Included & \\
\hline Industry Dummy & & Included & \\
\hline Adj. $R^{2}$ & & 0.310 & \\
\hline F value & & $8.76^{* * *}$ & \\
\hline Sample size & & 393 & \\
\hline
\end{tabular}

(1) Refer to 'THE MODEL (1), (2), and (3)' for the definition of variables.

(2) ${ }^{* * * * *}$, and ${ }^{*}$ significant at the $1 \%, 5 \%$, and $10 \%$ level, respectively.

In table 6, regression analysis using the scores of the government's management assessment as dependent variable found that the coefficient of firms using online issue was positive at a significance level of $1 \%$, indicating that firms issuing bonds online have better management assessment scores than firms using offline bond issue. If we assume that the scores of the government management assessment reflect the true status of public corporations, the regression analysis result can be quite significant. Putting the results from Table 4 and Table 5 together, it suggests the firms 
that issue bonds online has a high degree of transparency thus costs of capital and agency costs maybe lower, also firm value will be higher owing to less earnings management. Consequently, these firms may be graded higher in the government's assessment of management performance. Therefore, the result of regression analysis is consistent with the Hypothesis 3. Finally, multicollinearity is not a problem since every VIF value is low below 10.

\section{CONCLUSION}

If we assume that lower earnings management, more conservative accounting treatment, and higher scores of the management assessment by the government are attributes of firms with superior accounting characteristics, the results for these three attributes show that firms opting for online issue have better accounting characteristics than those opting for offline issuance. The results of this study, which covered only a few of the factors relevant in the primary bond market, were not significantly different from our initial expectation. These findings remind the managers responsible for bond issuance in public corporations of the consequences of their choice in the bond issuance method, and the brokers of investment banks that they need to be more competitive by providing services that add values rather than simply organizing the issuance process and receiving fees for it. These findings also indicate that external auditors need to be more careful when they audit public corporations that mainly employ the offline bond issuance method.

\section{AUTHOR BIOGRAPHY}

Soonwook Hong is a Professor, School of Business, Yeungjin College, Daegu, South Korea. E-mail: soonwookhong@yahoo.com

\section{REFERENCES}

Ahmed, A. S., Billings, B. K., Morton, R. M., Stanford-Harris, M. 2002. The role of accounting conservatism in mitigating bondholder-shareholder conflicts over dividend policy and reducing debt costs. The Accounting Review 77(4): 867-890.

Ahmed Anwer S, Duellman Scott. 2007. Accounting conservatism and board of director characteristics: An empirical analysis. Journal of Accounting and Economics 43(2-3): 411-437.

Ball. R., and L. Shivakumar. 2008. Earnings quality at initial public offerings. Journal of Accounting and Economics 45(3): 324349.

Dechow P. M., R. G. Sloan, and A. P. Sweeney. 1995. Detecting earnings management. The Accounting Review 70(2): $193-225$.

Edwards, A. K., Harris, L. E., Piwowar, M. S. 2007. Corporate bond market transaction costs and transparency. The Journal of Finance. 62(3): 1421-1451.

Hoje Jo, Yongtae Kim. 2007. Disclosure frequency and earnings management. Journal of Financial Economics 84(2): 561-590.

Hye-Jung Nam, Un-Seung Son, Kap-Soon Kim. 2013. The effect of the tax subsidy on accounting conservatism. Korean Journal of Taxation Research 30(2): 31-65.

In-Mu Haw, Simon S.M. Ho, Annie Y. Li, Feida Zhang. 2015. Product Market Competition, Legal Institution, and Accounting Conservatism. Journal of International Accounting Research 14(2): 1-39.

Jones. J. J. 1991. Earnings management during import relief investigations. Journal of Accounting Research 29(2): 193-228.

Seung-Hyun Oh. 2006. The study about bond electronic trading system. Korean Journal of Financial Management 12(1): 127161.

Soonwook Hong. 2016. The Effects of Capital Financing Types and Target Capital Structures on Earnings Management and Stock Returns. Hanyang University.

X. Chen, Q. Cheng, and X. Wang. 2015. Does increased board independence reduce earnings management? Evidence from recent regulatory reforms. Review of Accounting Studies 20: 899-933.

Xi, Li. 2015. Accounting Conservatism and the Cost of Capital: An International Analysis. Journal of Business Finance \& Accounting 42(5-6): 555-582.

Zhang, J. 2008. The contracting benefits of accounting conservatism to lenders and borrowers. Journal of Accounting \& Economics 45(1): 27-54. 